\title{
The Organizational Culture and Local Culture in the Internationalization Process: An Analysis Through Fuzzy Logic
}

\author{
Renato Dias Baptista ${ }^{1}$, Fernando Ferrari Putti ${ }^{2}$, Giuliana Aparecida Santini Pigatto ${ }^{1}$, Camila Pires Cremasco Gabriel, \\ Luís Roberto Almeida Gabriel Filho ${ }^{1}$ \\ ${ }^{1}$ Associate Professor, São Paulo State University, UNESP, Brazil \\ ${ }^{2}$ Assistant Professor, São Paulo State University, UNESP, Faculdade de Ciências e Engenharia, Brazil \\ Correspondence: Renato Dias Baptista, Associate Professor, São Paulo State University, UNESP, Brazil.
}

Received: October 11, 2019

doi:10.11114/ijsss.v8i2.4562

\author{
Accepted: February 3, $2020 \quad$ Available online: February 12, 2020 \\ URL: https://doi.org/10.11114/ijsss.v8i2.4562
}

\begin{abstract}
The internationalization process of production has marked the world scenarios since the last decades and has influenced the complex interrelationships between the local culture and organizational culture. The culture shock was a recurring phenomenon and made the internationalization started to absorb elements of local culture as determining factors in expansion strategies. The aim of this paper is to analyze the favorable conditions of the organizational culture to manage the local culture. This is a preliminary study that aimed to integrate qualitative and quantitative factors with a fuzzy logic system. To achieve this goal, three elements were analyzed and interrelated: values, organizational structure, and management practices of human resources. A fuzzy mathematical model that considers the different weights to the elements analyzed leading to the identification of the favorability of the organizational culture in managing the local culture was developed. Petrobras, a transnational corporation with unity in Bolivia, whose major shareholder is the Brazilian government, was studied to empirically identify how the elements interact and are incorporated into internationalization strategies.
\end{abstract}

Keywords: culture, organization, fuzzy system, Mamdani, Petrobras

\section{Introduction}

Studies on the internationalization process of companies in emerging and developing countries have increased in this twenty-first century, motivated by the understanding of an intense work of the organizations, whether in Latin American markets (mainly after the 1990s), either in developed markets (more specifically in the last decade). Some works that have made contribution to this process in the literature, from a strategic point of view, can be cited as Gaur, Kumar, Singh (2014), Ciravegna, Lopez and Kundu (2014), Kumar, Mudambi and Gray (2013) and Fleury, Leme Fleury and Borini (2012), but there is still vast field to be explored, especially about the relation between organizational culture and local culture in processes of productive internationalization, focus of this work.

Concerning Brazil, it can be said that the 1990s also expressed the internationalization of national companies, with a significant expansion of direct investment. These investments occur when companies invest or acquire the plant, equipment or other assets outside their country of origin. Brazilian direct investment abroad has advanced from an average amount of \$ 1 billion / year in the period 1990-2000 to the average amount of US \$ 4.8 billion / year in the period 2001-2013 (Central Bank, 2014).

Among the leading factors of this process, it can be mentioned: economic and intensification of foreign trade post-1990; the cooperation agreement among the countries, MERCOSUL; the privatization operations of state-owned enterprises and the consolidation of the consumer goods industry; the denationalization of the durable goods industry; the saturation of local demands and the need for global economies of scale (Fleury, Leme Fleury, and Reis, 2010; Kumar, Mudambi and Gray, 2013).

In the case of Brazilian investments in Bolivia, although compared to investments in other South American countries, the financial amounts are not the most expressive (the exemplification, US\$ 82 million on average for the period 2007-2013, compared to investment US\$ 4.3 billion in Argentina and US \$ 2.5 billion in Uruguay, according to Central Bank (2014)), the relevance of the Brazilian presence in the country is given otherwise. This would be the profile of 
locus sector investments (oil industry/energy that has an important strategic role supply to many countries around the world), and as a result, Petrobras, which has a history of public-private investment and economic and strategic relevance to Brazil.

Petrobras has a business in Bolivia in prospecting and exploration of oil and natural gas, and foreign investment to the sector fostered mainly after 1998 with the construction of the pipeline to Brazil. The investment-related to the Bolivia Brazil pipeline cost, according to Chávez (2008), was more than US\$ 2 billion, constituting an infrastructure work of 3,069 kilometers, and it is an important step towards bilateral energy complementarity and resulted in stronger presence of FDI, both Brazilian and other countries (Chávez, 2008). According to Ruegenberg (2009), the fact that natural gas is transported by pipeline requires that most natural gas sales contracts in the world are bilateral and long-term ones since they require significant investment in transport.

Besides the political and economic characteristics, there are also cultural peculiarities evidenced in the country. Bolivia has a complexity that must be deciphered. Roads are constantly closed by natives who see in this attitude the way to appeal against an unfavorable daily routine.

However, a conflict manifestation is the result of a network of interconnected events. These elements need to be added to the cultural analysis of Bolivia to provide information to the internationalization process. Barriers should not be considered as isolated, they also provide the development of future strategies for organizations that intend to expand in Bolivian lands. It should be taken into account the multiple ethnic groups, besides the variables of internal policies and international relations.

As we take the case of Bolivia, we aim to analyze the actions of Petrobras in unraveling the complexity of local culture as an essential aspect of the internationalization process. Managerial human resource practices, values, and organizational structure analyzed using a mathematical model based on artificial intelligence allows us to identify the competence level related to the integration of local culture in their internationalization strategies. Such modeling consisted of a system based on fuzzy rules, able to use expert information for the development of that weighting. It is a methodology of approximate reasoning, similar to the form of human thought. In these cases, linguistic variables are represented by fuzzy sets, interpreting a linguistic variable as a variable whose values are words or sentences in natural language, in addition to the existence of variation in options (Zadeh, 1965).

This type of analysis has shown efficacy in studies of human resources actions, as shown in Jianchang Lu (2011), Zemková (2011) and Fuller et al. (2012). Ishii and Sugeno (1985) used a mathematical model for the process of human subjective assessment. Swigger et al. (2004) highlighted the relationship between cultural factors and the performance of teams. Martinez-Miranda et al. (2010) proposed a combination of the demands of managers and individual characteristics using fuzzy logic.

\section{Theoretical Framework}

In the organizational context, culture is analyzed and integrated into all transitions. According to Morgan (2012), culture is part of the ideology, values, laws and daily rituals. According to the assumptions of Sahlins (2003), the ideas that men elaborate on the world come from the knowledge and experience articulated in the world. These aspects function as a collective programming of the mind (Hofstede, 2003).

The concepts of culture are adapted to the reality of organizations according to Kotter and Heskett (1994), Schein (1986), Deal and Kennedy (1997) and Keyton (2005). Deal and Kennedy (2001, p.21) conceptualize the values as the foundation of any culture. As the essence of philosophy, values feed a sense of common direction and guidelines for day-to-day behavior. These formulas for success determine the types of heroes, myths, rituals, and ceremonies of the culture.

Adler (2007) reinforces the concept of values stating that they are desirable for the group or the individual and influence the choice of valid habits. Values are comprised of strategies and work philosophies, and they reflect in the artifacts that represent the visible characterization. According to the assumptions of Adler (2007) and Spector (2012), culture influences the behavior of organizations and people's behavior within organizations. Organizational culture tends to encompass external variables since a company is an open system. In this respect, an organizational culture requires a study of the local culture. The social context in which the company operates provides essential elements for the effectiveness of the organizational culture.

The structure, in turn, reflects the values of an organization. For Mintzberg (2006), the structure includes clarity, motivational impact, internal consistency, compatibility with the environment, adequacy in the light of resources, degree of risk, time horizon, and functionality. The structure is a component that influences the results of the organization. In this respect, the structure absorbs the hierarchical typology and management control systems. Business structures can be vertical or horizontal; they can be arranged as a whole, in functional units, or business units. They can 
be centralized or networked (Rudy, 2014).

For Mintzberg (2006), the structure, systems, and organizational processes are specific to the development of a strategy. An organizational structure must be put in place by information systems and relationships. Organizational processes of human resources, such as performance evaluation, remuneration, and management development must be geared to the type of behavior required by the organizational goal. Furthermore, the lead role is important, sometimes decisive for carrying out the strategy.

The practices and policies needed to drive the aspects related to people at work are the responsibility of human resource management (HRM). Among the practices and policies are: lead to job analysis, predicting labor needs, recruit and select, guide and train new employees, manage rewards and wages, offer incentives and benefits, assess performance, communicate (interviewing, counseling and disciplining), train and develop, build employee engagement (Dessler, 2011).

To Deadricka and Stoneb (2014), the strategic role of human resources had a beginning in the 1980s. In that period working methods based on participatory systems from the Japanese administration were introduced. Kira and Balkin (2014) emphasize that it is possible to evaluate the benefits of human resource management practices while maintaining alignment between the strategies of the company arising from the dome and the actions directed to the worker.

Human resources are critical in maintaining the values; moreover, they act as support to the organizational structure. They are crucial for a company to manage the internal and external variables of an internationalization process.

The pressure of the variable drives organizational changes that, by the time, will comprise elements of culture.

2.1 Fuzzy Logic

Mathematical modeling would materialize a more comprehensive understanding of science since it is possible to make conclusions about situations not observed before and determine overall results for the entire study area (Pereira et al., 2008). The ways the fuzzy systems are studied and applied make it possible to create this type of modeling, also using the statistical analysis of the phenomenon under study. Thus, these fuzzy systems are applications coming to help, (i) locally with the analytical power of the studied phenomenon and creation of conclusions that could not be set out before, and (ii) globally, with the consolidation of a form of using a theory that may ultimately become the most natural way of performing mathematical modeling by researchers from different fields of knowledge (Putti, et al., 2014).

\subsection{Fuzzy Sets}

Let $U$ be any set, called a universal set. The fuzzy subset $F U$ is characterized by the function $\mu: U \rightarrow[0,1]$ called the membership function of the fuzzy set $F$. The rate $\mu(x) \in[0,1]$ indicates the degree that the element $x U$ is in the fuzzy set $F$, with $\mu(x)=0 \mu(x)=1$ and respectively indicating non-membership and complete membership of $x$ the fuzzy set $F$ (Zadeh, 1965).

Fuzzy membership functions represent the basic aspects of all the theoretical and practical actions of fuzzy systems. A membership function is a numerical graph or tabulated function that attributes fuzzy membership rates to the rates of a variable in a universal set. A whole variable represents the numerical interval of all possible true rates that a specific variable may take (Peixoto, 2005).

\subsubsection{Operations Between Fuzzy Sets}

Fuzzy sets of all entrance variables were defined as a membership function in a triangular form, given by:

$$
\mu_{A}(x)=\left\{\begin{array}{lll}
0, & \text { if } & x \leq a \\
\frac{x-a}{b-a}, & \text { if } & a<x \leq b \\
\frac{x-c}{b-c}, & \text { if } & b<x \leq c \\
0, & \text { if } & x>c
\end{array}\right.
$$

The graph of a triangular fuzzy number has the form of a triangle (Figure 1), with the interval $[a, c]$ as base and point $(b, 1)$ as the only vertex outside the base. Consequently, the true numbers $a, b$ and $c$ define the triangular fuzzy number $A$. 


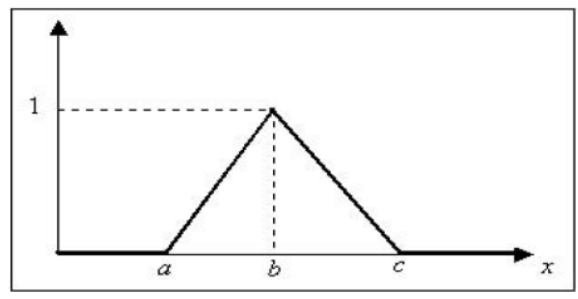

Figure 1. Triangular model of the fuzzy system

\subsubsection{Fuzzy Rule-Based Systems}

A system based on fuzzy rules has four components: an input processor (fuzzification), a set of linguistic rules, a fuzzy inference method and a processor output (defuzzification), which produces a real number as output (Ribacionka, 1999).

The controller structure represents the transformation from the true world domain, which uses real numbers, to the fuzzy domain, which employs fuzzy numbers. During transformation, a set of fuzzy inferences is employed for decision- making. There is finally an inverse transformation from the fuzzy domain to the real world domain so that the coupling between the fuzzy algorithm output and the variables occurs (Shaw \& Simões, 1998).

Fuzzification is a process by which the system's input rates are converted in to fuzzy sets with their respective rate bands where they are defined. It maps the domain of real numbers for the fuzzy domain. Fuzzification also represents linguistic rates attributions, diffused or qualitative descriptions, defined by membership functions to input variables. Fuzzification is, therefore, a sort of preprocessing of categories or input sign classes which greatly reduce the number of rates to be processed. A less amount of rates processed means that a faster computation exists (Pedrycz \& Gomide, 1998).

A linguistic variable $u$ may be associated with a set of linguistic terms by the function $T(u)$. These terms may be fuzzy numbers over a universe set $U$.

The base of rule characterizes the aims and the strategy used by specialists in the area by a set of linguistic rules.

The logic of decision-taking, incorporated within the inference structure of the rule base, employs fuzzy implications to simulate human decision-making. It produces actions, or consequences, inferred from a set of entrance conditions, or antecedents.

Mamdani's inference method, employed in current research, aggregates rules by the logic operator OR, modeled by the mathematical operator with $\vee$ and, in each rule, the logical operators $A N D$ and THEREFORE are modeled by the minimum operator $\wedge$ (Barros \& Bassanezi, 2006; Massad, et al., 2008).

\section{Materials and Methods}

It is research of an applied nature, descriptive about the objectives and with a qualitative approach and fuzzy logic system of analysis. The research was conducted in the years 2012-2014 at Petrobras, a public trade company whose major shareholder is the Brazilian government. The company integrates the energy segment in the following sectors: exploration and production, refining, marketing, transportation, petrochemicals, distribution of oil, natural gas, electric power, gas-chemical and bio fuels. Besides Brazil, it is present in 17 other countries (Petrobras, 2014).

The research looked specifically at the Petrobras unit in Bolivia to identify the values, human resource management practices and organizational structure (Structures in the figures) about the Bolivian cultural variables. The data allowed the study of the factors analyzed and made possible the development and construction of the fuzzy rule-based model. Data collection was carried out at the offices of Petrobras Bolivia in Santa Cruz de la Sierra and a production plant in Tarija/Bolivia, specifically in the 'San Antonio' unit. The mega field of San Antonio is located in the state of Tarija, in the region called 'El Gran Chaco' and which houses one of the largest natural gas reserves in Bolivia. In this region, Petrobras operates in the exploration, production, and transportation of natural-gas through pipelines.

In this sense, the proposed fuzzy model aims to understand the relationships between determining elements that lead to the degree of favorability of changing the culture (exit from the model). Such a system, classified as a specialist system, is governed by a mathematical model that makes it possible analytically and graphically to visualize all possible combinations between such determining factors, showing how exactly the model leaves the cause.

\subsection{Fuzzy Modeling}


For the creation of a system based on Fuzzy Logic (Figure 2), it was necessary to define an input processor (or fuzzification), a set of linguistic rules, a Fuzzy inference method (Mamdani) and an output processor (or defuzzification) which generates a real number as output, as well as defined by Gabriel Filho et al. (2011) and Cremasco et al. (2010).

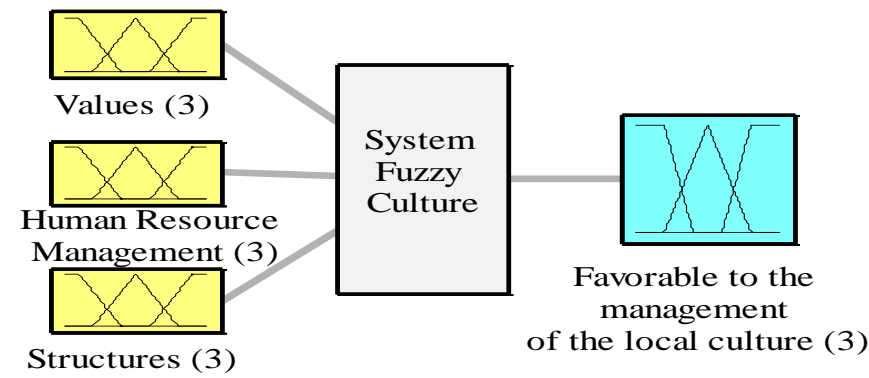

Figure 2. A system based on Fuzzy Logic for determining the favorability of changing the culture

The membership functions of the variables of the proposed Fuzzy System were defined in 3 pertinence functions called "Low" (L), "Medium" (M) and "High" (H). These functions have been defined based on the analysis of data collected, in which it was observed that there were three groups, so the nomenclature for input and output sets was adopted.

The construction of fuzzy sets has been prepared following Table 1, in which the range varied from 0 to 10 , being thus symmetrically distributed among the membership functions.

Table 1. Definition of membership functions of input and output variables

\begin{tabular}{lll}
\hline Fuzzy Set & Kind & Delimiters \\
\hline "Low" $(\mathrm{L})$ & Trapezoidal & {$\left[\begin{array}{lll}-1 & 0 & 1\end{array}\right]$} \\
\hline "Medium" $(\mathrm{M})$ & Triangular & {$\left[\begin{array}{lll}2 & 5 & 8\end{array}\right]$} \\
\hline "High" $(\mathrm{H})$ & Trapezoidal & {$\left[\begin{array}{llll}6 & 9 & 10 & 1\end{array}\right]$} \\
\hline
\end{tabular}

The input variables in the proposed Fuzzy Logic based system were "Practical Management of Human Resources", "Organizational Structure" and "Organizational Values" and the output variable was named "Degree of competence for managing the local culture "(Figure 3, 4, 5 and 6).

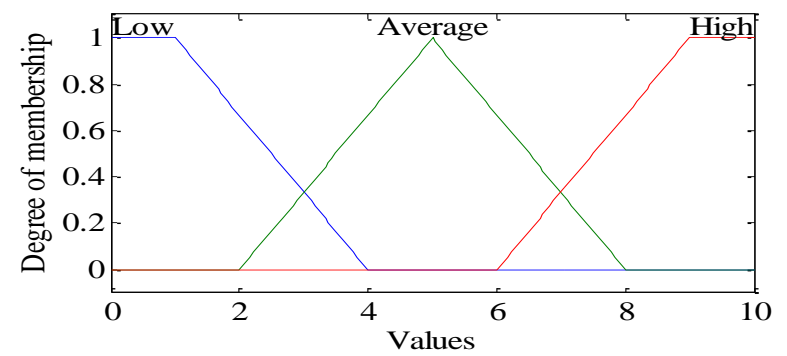

Figure 3. Membership functions defined for the Fuzzy sets the "Values" input variable

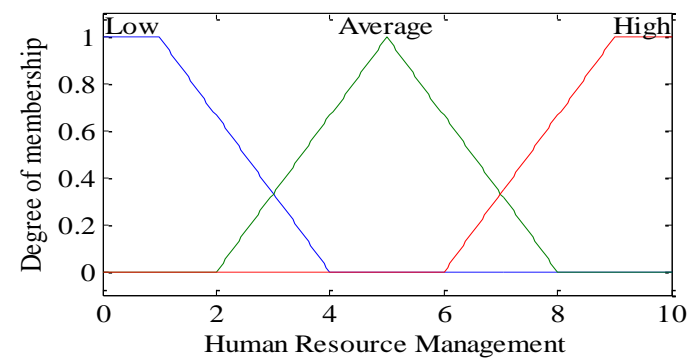

Figure 4. Membership functions defined for the fuzzy sets of "Practical Managements" input variable 


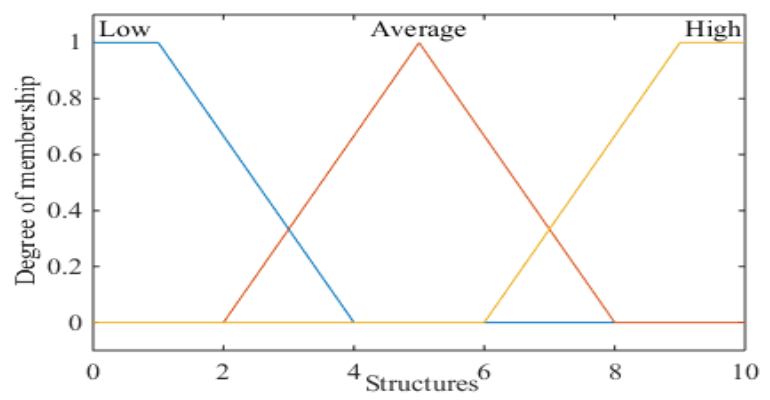

Figure 5. Membership functions defined for the fuzzy sets of the "Structures" input variable

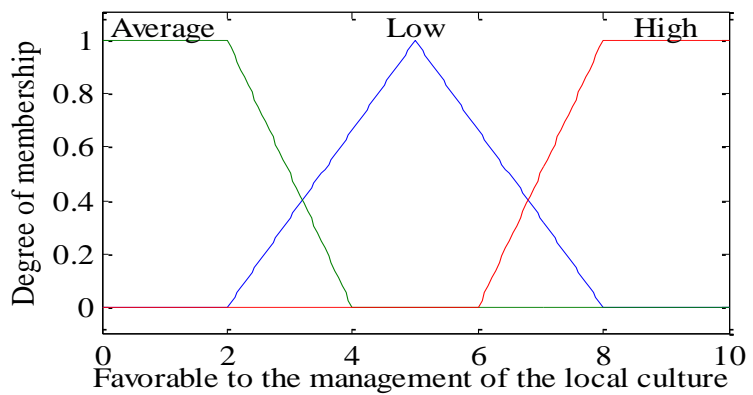

Figure 6. Membership functions defined for the Fuzzy sets of output variable "Culture" conducive to change

To obtain the rule base in the fuzzy system, it was considered the $27(3 \times 3 \times 3)$ combinations of fuzzy sets of input variables, being created 27 sets to begin analyzing the fuzzy system; the additional information of rules was supplied by a specialist.

The method of inference or fuzzification adopted was the Mamdani method, which combines the degrees of the pertinence of each of the input values, through the minimum operator, and aggregates the rules by the maximum operator. Given a set of values for the input variable, the system obtains a fuzzy set, such as the value of the control variable. This fuzzy set represents an ordering of control actions acceptable at that time. Finally, a global control action was selected from those acceptable, in a process known as defuzzification (Sandri \& Correa, 1999). The defuzzification was obtained by the area center (COA), in which the exit center is the center of gravity of the possibility distribution function of the control action (Mamdani, 1976; Amendola et al., 2004).

The inference method used to calculate the numerical value of the output variables, according to Rule Base, was Mamdani (Cremasco, et al., 2008).

So, from the development of the model, it was possible to determine the favorability of management for the local culture through the following expression:

$$
F A V=\frac{P G *(\mu)+V A *\left(\mu^{\prime}\right)+E S *\left(\mu^{\prime \prime}\right)}{\mu+\mu^{\prime}+\mu \prime \prime},
$$

In which FAV is the Favorability, PG is an abbreviation for management practices, VA is an abbreviation for values, ES is an abbreviation for organizational structure and $\mu$ is the weight that each variable has in the answer.

With the help of the Fuzzy Logic Toolbox software MATLAB® 7.0 tool, it was possible to create a fuzzy logic-based system, also being given a surface and a contour map for the representation of the system.

\subsection{Description of the Studied Company}

Petrobras' Bolivian unit has 520 employees. The production plants operated by Petrobras in Bolivia are surrounded by peasants with strong migration from the Bolivian high lands in search of work sources and better quality of life and Weenhayek people who are in the province of Gran Chaco, in the state of Tarija. They inhabit a vast plain forest, 
degraded land, with few rivers due to the dryness of the environment and which expand in the rainy season. These are lowlands that intersect with Bermejo, Pilcomayo, and Villamontes (Rivero, 2013). In the presence of indigenous Weenhayek groups, it has become crucial to know them so that this action/information could be integrated into the strategies for using the area where the plants are located in San Alberto and San Antonio. The action of listening, negotiating and respecting the different communities is embedded in the daily procedures of communication management and social responsibilities and incorporated into the organizational culture.

However, the organizational structure presents a sharp bureaucracy following the guidelines of a state company with businesses in other countries.

The company's values are managed to be integrated into the local culture, but they are constantly subject to changes in political issues in Bolivia. Negotiations with indigenous groups and peasants are constantly taking into account prospecting in indigenous areas.

The management practices of human resources apply modern communication actions, social responsibility, compensation, and benefits, training, performance evaluation. Social projects, Table 2, represent an integration to the local culture strategy.

Table 2. Social Projects by Petrobras Bolivia

\begin{tabular}{|c|c|c|}
\hline No. & Project & Description \\
\hline 1 & $\begin{array}{l}\text { Qualification Program for } \\
\text { Professional Experience }\end{array}$ & $\begin{array}{l}\text { The objective of the Project is to certify practical work experience of workers in the area of } \\
\text { influence of its operation (Chaco) to strengthen the skills that allow multiplying their job } \\
\text { options from training and qualification programs. }\end{array}$ \\
\hline 2 & $\begin{array}{l}\text { Development and Promotion of } \\
\text { Productive Projects }\end{array}$ & $\begin{array}{l}\text { The goal of this project is to improve income generation among the inhabitants of the } \\
\text { communities in the areas of influence of Petrobras' operations (Chaco), by strengthening the } \\
\text { skills for community development with a focus on production and trade. }\end{array}$ \\
\hline 3 & $\begin{array}{l}\begin{array}{l}\text { Qualification for } \\
\text { entrepreneurs } \\
\text { entrepreneurs of Chaco }\end{array} \\
\text { and }\end{array}$ & $\begin{array}{l}\text { To support companies in the area of Chaco developing their potential through professional } \\
\text { qualification and experience of microenterprise management, aiming to promote the hiring } \\
\text { of services by the oil industry and institutions, and most representative companies in the } \\
\text { area. }\end{array}$ \\
\hline 4 & $\begin{array}{l}\text { Childhood counts, Micro, and } \\
\text { educative Radio programs }\end{array}$ & $\begin{array}{l}\text { The project aims to promote environmental education and respect for children's and } \\
\text { adolescents' rights through radio micro-programs broadcasted by the media of the Bolivian } \\
\text { Chaco, to strengthen the responsibility of the three sectors of society. }\end{array}$ \\
\hline 5 & Sports Clinics, Fair Play & $\begin{array}{l}\text { The project includes technical and tactical training for children between } 2-15 \text { years old, } \\
\text { trainers, coaches, and technical directors and physical education teachers of the Chaco } \\
\text { region, supported by training for parents in education and preventive health. Soccer } \\
\text { instructors perform internships in Santa Cruz, where they learn the techniques and then } \\
\text { apply them in their schools. }\end{array}$ \\
\hline 6 & $\begin{array}{l}\text { Mobilized and United on } \\
\text { behalf of the Environment }\end{array}$ & $\begin{array}{l}\text { The project "United and Mobilized on behalf of the Environment" is intended for students of } \\
\text { elementary and secondary education of all educational Chaco units of the Caraparí } \\
\text { community. It consists of the presentation of a group project related to environmental issues } \\
\text { in their community, such as recycling, waste, and others by proposing alternative solutions. }\end{array}$ \\
\hline 7 & Corporate Volunteering & $\begin{array}{l}\text { As part of its Social Responsibility policy, implemented across the board throughout the } \\
\text { organization, Petrobras incorporates support from its workforce through volunteer actions. } \\
\text { This stable and organized group engages in activities articulated to social projects and } \\
\text { corporate sponsorships. In 2011, eight projects were developed, involving about } 100 \text { active } \\
\text { volunteers and the participation of the entire company in specific and solidarity activities. }\end{array}$ \\
\hline 8 & $\begin{array}{l}\text { Boa Pinta Neighborhood } \\
\text { Project }\end{array}$ & $\begin{array}{l}\text { The Boa Pinta Neighborhood Project steadily seeks citizen participation in the recovery, } \\
\text { improvement, and maintenance of public spaces. It develops through contests, in which } \\
\text { neighborhoods compete with projects to improve squares, parks, and schools. }\end{array}$ \\
\hline 9 & Carpa de Teatro (Theater Carp) & $\begin{array}{l}\text { The project promotes environmental education and respect for the rights of children and } \\
\text { adolescents through theatrical presentations in large public spaces in the city seeking to } \\
\text { strengthen the responsibility of the three sectors of society on these issues. }\end{array}$ \\
\hline
\end{tabular}

Source: Petrobras, 2015.

However, these actions do not exempt the complexities of local culture and the current government policies that tend to a nationalization process.

Internally, the organizational climate survey ${ }^{1}$ conducted in 2012 showed a satisfaction rate of $75 \%$. The commitment

${ }^{1}$ Process of measuring the "employee perception" of an organization. In this case, the Petrobras Company presented
the final result about the research that the human resources department diagnosed. This research is a set of properties of 
with the company had a rate of $79 \%$ obtained in consequence of a very strong practice of internal communication.

The unit has a communication program that is divided into three areas. The first is related to programs aimed at the participation and involvement of employees in Petrobras programs and processes enhancing the strategic aspects, the vision, and the company's mission.

Externally, the area of human resources acts closely and integrated with the communication area, once the area where the production plants are located demands a support network to the community.

The values ${ }^{1}$, in turn, even seeking for interfaces with the local culture, fail to incorporate the external dynamics of Bolivia, demonstrating, according to data obtained, that Bolivia is a country with weak public structures and conflicting ideological positions. Moreover, there is the fact that recent corruption cases highlighted in the Brazilian unit reverberate negatively on production plants located in other countries.

\section{Results and Discussion}

\subsection{Fuzzy Rules for the Developed System}

From the determination of fuzzy sets and the collection of additional data held with the expert, it was possible to determine the ground rules for the construction of the fuzzy rule-based model (Table 3).

Table 3. The base of rules on the Fuzzy Logic based system

\begin{tabular}{|c|c|c|c|}
\hline Input Variables & & & Output Variables \\
\hline Values & Management Practices & Structures & Culture \\
\hline $\mathrm{L}$ & $\mathrm{L}$ & $\mathrm{L}$ & $\mathrm{L}$ \\
\hline $\mathrm{L}$ & $\mathrm{L}$ & A & $\mathrm{L}$ \\
\hline $\mathrm{L}$ & $\mathrm{L}$ & $\mathrm{H}$ & $\mathrm{L}$ \\
\hline $\mathrm{L}$ & A & $\mathrm{L}$ & $\mathrm{A}$ \\
\hline $\mathrm{L}$ & A & A & A \\
\hline $\mathrm{L}$ & A & $\mathrm{H}$ & A \\
\hline $\mathrm{L}$ & $\mathrm{H}$ & $\mathrm{L}$ & $\mathrm{L}$ \\
\hline $\mathrm{L}$ & $\mathrm{H}$ & A & A \\
\hline $\mathrm{L}$ & $\mathrm{H}$ & $\mathrm{H}$ & A \\
\hline $\mathrm{A}$ & $\mathrm{L}$ & $\mathrm{L}$ & A \\
\hline A & $\mathrm{L}$ & A & A \\
\hline A & $\mathrm{L}$ & $\mathrm{H}$ & A \\
\hline A & A & $\mathrm{L}$ & A \\
\hline A & A & A & A \\
\hline A & A & $\mathrm{H}$ & $\mathrm{A}$ \\
\hline A & $\mathrm{H}$ & $\mathrm{L}$ & $\mathrm{H}$ \\
\hline A & $\mathrm{H}$ & A & $\mathrm{H}$ \\
\hline A & $\mathrm{H}$ & $\mathrm{H}$ & $\mathrm{H}$ \\
\hline $\mathrm{H}$ & $\mathrm{L}$ & $\mathrm{L}$ & A \\
\hline $\mathrm{H}$ & $\mathrm{L}$ & $\mathrm{A}$ & A \\
\hline $\mathrm{H}$ & $\mathrm{L}$ & $\mathrm{H}$ & A \\
\hline $\mathrm{H}$ & A & $\mathrm{L}$ & $\mathrm{H}$ \\
\hline${ }^{2} \mathrm{H}$ & $\mathrm{A}$ & $\mathrm{A}$ & $\mathrm{H}$ \\
\hline $\mathrm{H}$ & A & $\mathrm{H}$ & $\mathrm{H}$ \\
\hline $\mathrm{H}$ & $\mathrm{H}$ & $\mathrm{L}$ & $\mathrm{H}$ \\
\hline $\mathrm{H}$ & $\mathrm{H}$ & $\mathrm{A}$ & $\mathrm{H}$ \\
\hline $\mathrm{H}$ & $\mathrm{H}$ & $\mathrm{H}$ & $\mathrm{H}$ \\
\hline
\end{tabular}

Table 3 shows the base of rules for the fuzzy system.

Such a rule base represents the main part of the model since it is the link between the experts' understanding and the model's interpretation of this information. It is worth mentioning that such a base of rules also constitutes an important result in understanding the phenomenon studied in this work since all linguistic cause and effect information is represented there. This procedure was used similarly by Gabriel Filho et al. (2015), Pereira et al. (2008) and Putti et al. (2014, 2017).

In this way, as shown in the example, the first 3 lines represent relationships:

the work environment, perceived by the employees and that is assumed to be a major force in influencing employee behavior and the cultural variables.

1. Petrobras Values: Our actions and business are guided by values that encourage sustainable development, integrated performance and accountability for results, promoting readiness to change and the spirit of enterprise innovation and overcoming challenges. 
- If (values is "L"), ( HRM Management Practice is "L") and (Structure is "L") then ( Culture is "L");
- If (values is "L"), (HRM Management Practice is é "L") and (Structure is "A") then (Culture is "L");
- If (values is "L"), (HRM Management Practice is é "L") and (Structure is "H") then (Culture is "L");

The others are analyzed in similar ways.

\subsection{Favorability Analysis for Local Culture Management About Changes in HRM Management Practices and Values}

Managerial human resources practices are intrinsically related to the organization's values and this factor makes possible the management of the local culture. In Figure 7, it is noted that the area in red shows the points that the organization must be so that the culture has favorability management of local culture.

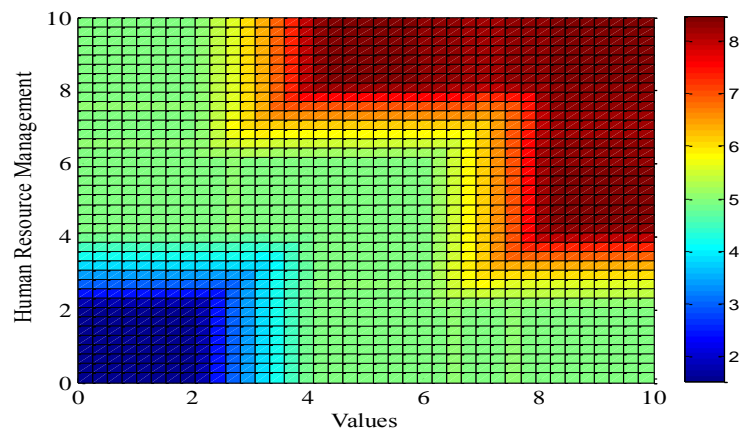

(a)

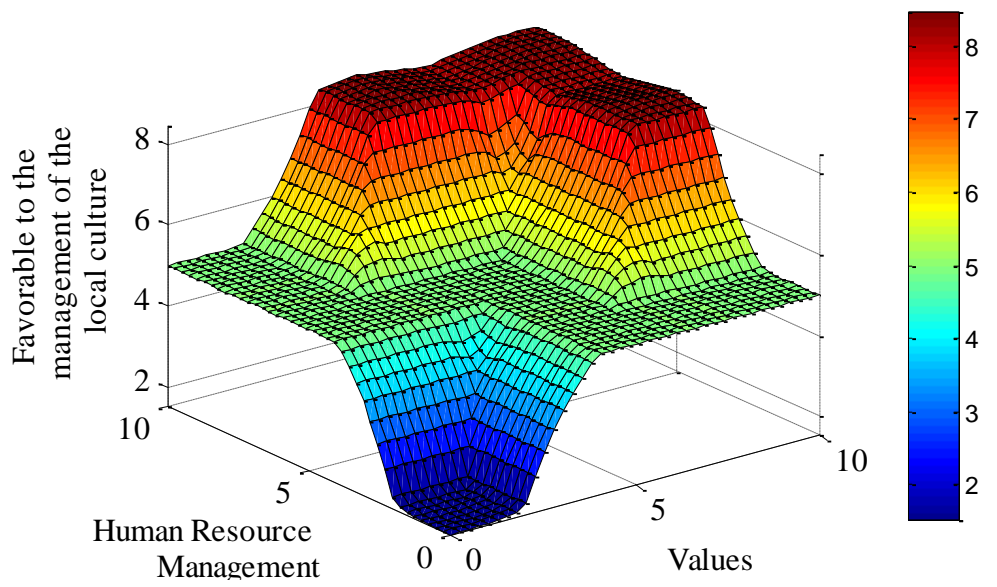

(b)

Figure 7. Analysis of change favorability in terms of management practices and values, (a) Three-dimensional representation and (b) Contour map

It can be seen that in Figure $7 \mathrm{a}$ an increase in values and human resource management practices entail an increase in favorability of local culture management. Figure $7 \mathrm{~b}$ shows that region A presents the $\mathrm{X}$-axis with very low management favorability, making the possibility of managing the local culture more difficult. On the other hand, in the region B, it is noted that an increase related to values or managerial practices brings in a process of evolution, in making the company's ability to manage the local culture ordinary.

For region $\mathrm{C}$, which has favorability close to the region which would be ideal, organizations must observe which variables are more deficit to evolve the current situation and lead the organization to act accordingly to region $\mathrm{D}$.

It should be emphasized that there are situations that it is no more needed increase in managerial practice variables of human resources or values so that the organization has the management "Favorability" of the local culture at a high level. Those are the cases of organizations: (i) with high "managerial practices of human resources" and intermediary "values" or (ii) with high "values" and intermediary "managerial practices".

It should be noted that, even if the organizations present almost ideal human resources management practices and intermediate levels of values, the organization presents favorability to manage the local culture as well as to present the almost ideal values and intermediate managerial practices. 


\subsection{Favorability Analyses for Management of the Local Culture Relating to Changes in the Structure and Values}

By analyzing the structure and values of the organizations at the expense of favorability, we note that the organizational structure depends on the values for the organization to present an evolution in the management of the local culture.

The region is in red presents the ideal condition for companies to be at the time of cultural evolution (Figure 8).

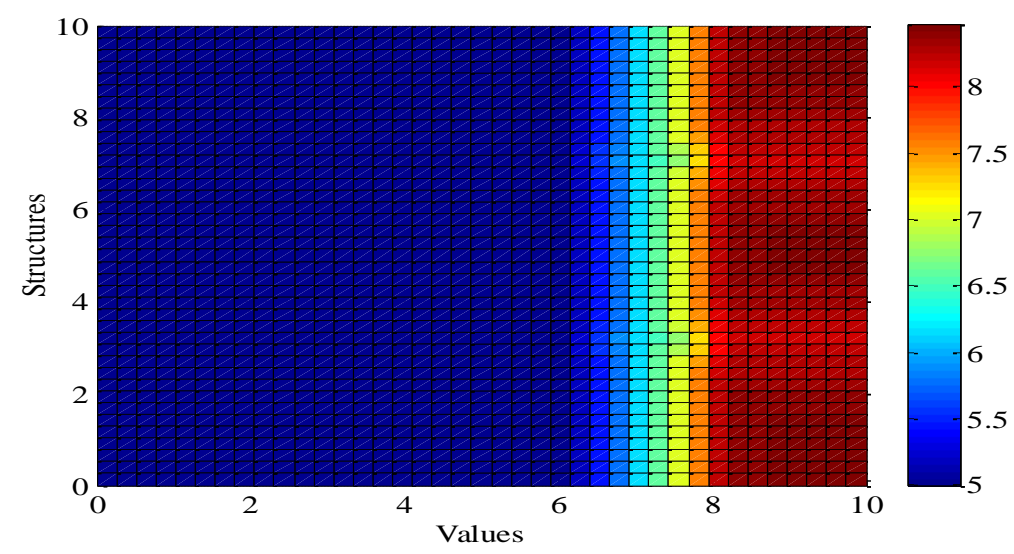

(a)

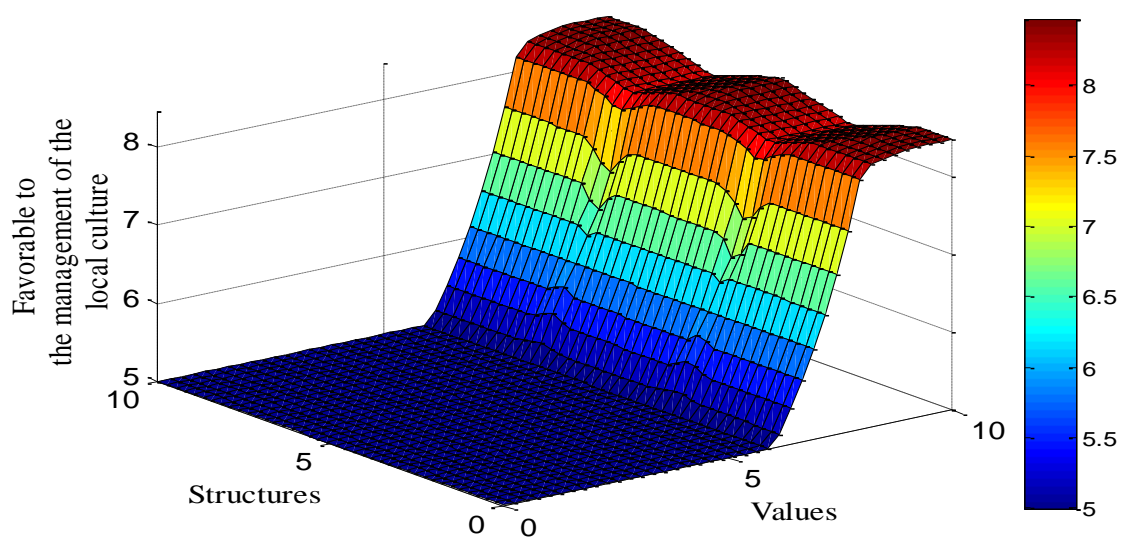

Figure 8 . Analysis of the favorability of culture change depending on the values and structure: (a) Three-Dimensional representation and (b) Contour map

Figure 8a shows the favorability to the management of local culture relating to values and organizational structure. In analyzing, it is observed that the organizational structure is not interfering with the ability of management. Thus, the "values" are considered the major variable, as to analyze the region A; it appears that until the strip 6, the organization is not vulnerable to the culture management, regardless of how the organizational structure is coordinated.

The region $\mathrm{B}$ is the intermediate region in the process that is between points 6 and 8 . As seen, in this region there is no interference of the structure. Similarly, it was found that in the area of point $\mathrm{C}$, the major factor that promotes management is the values. In this region, the classification structure (Low, Medium and High) does not interfere with favorability to culture management.

4.4 Favorability Analyses for Management of the Local Culture Relating to Changes in the Structure and Practices of HR Management

In the analysis of management HR practices and organizational structure that favor the management of culture, it is observed that the structure does not generate interference. Thus, managerial practices have high participation in this organizational development process. Therefore, management practices need to be addressed more closely within the organization, because it is a factor that directly interferes in the favorability process. (Figure 8). 


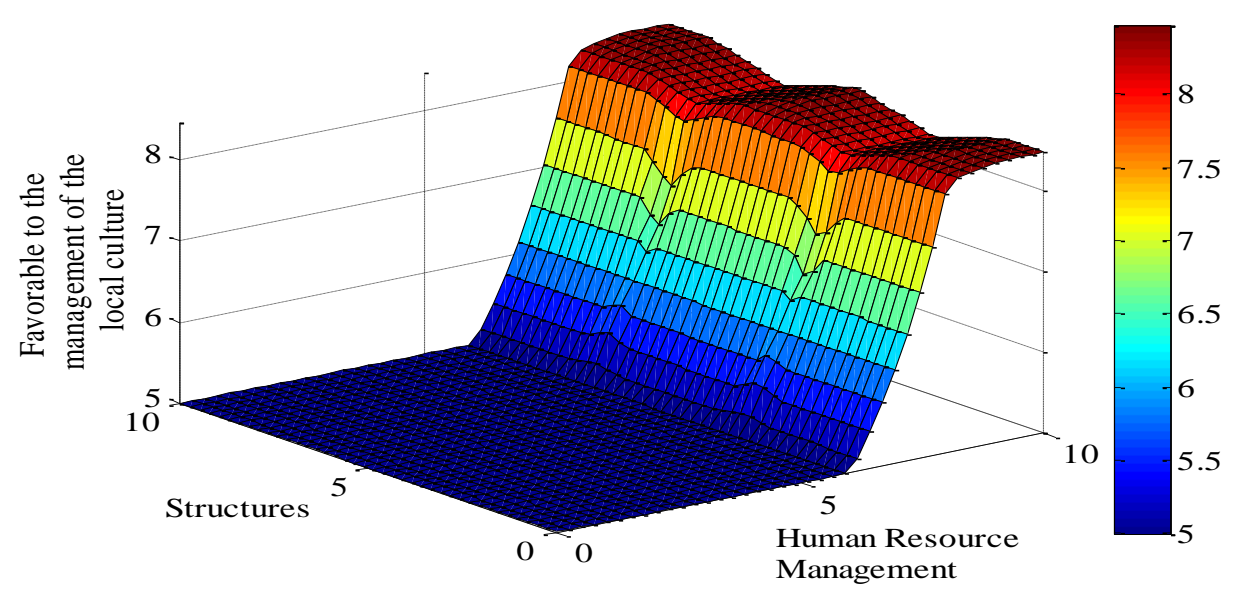

(a)

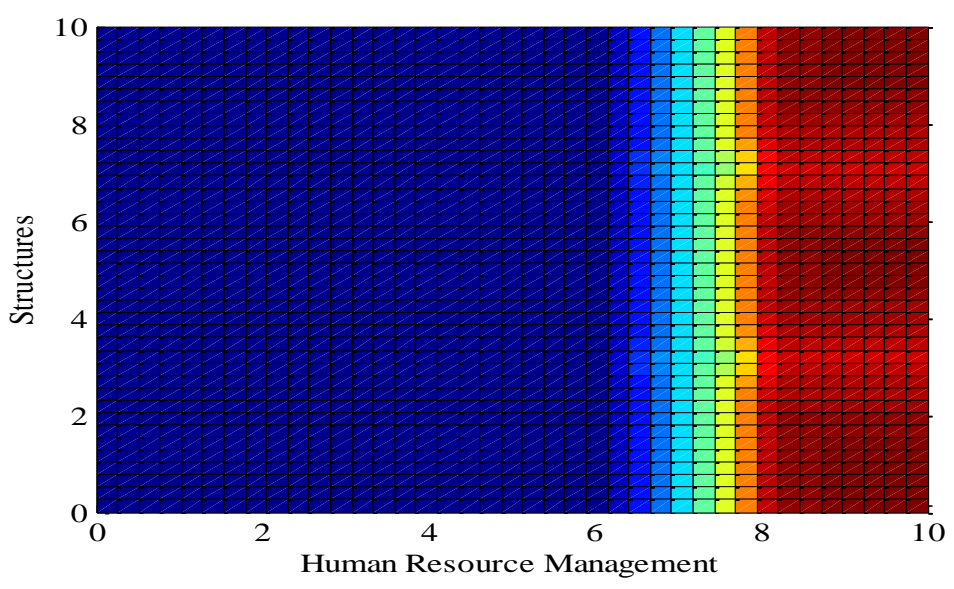

(b)

Figure 9. Analysis of change favorability depending on the organizational structure and HR management practices; (a) Tri-sizing representation and (b) Contour map

Figure 9a shows the relationship process between managerial practices and organizational structure, and that the major factor for the evolution of culture management is the human resource practices adopted. It can be seen that in Region A, the organization is a cast, once it does not present conditions that can favor the management.

As for region B, it can be noted that the structure showed no interference in the evolution compared to Region A. In this intermediate region is a transitional process so that the organization can meet the ideal conditions for the favorability of culture management.

Region $\mathrm{C}$ is the region that would be the ideal one, considering that if the organization is between 8 to 10 in management practices, it will not present interference of the type of organizational structure that the company has.

\subsection{Application of the Proposed Model}

"The ability of the human mind to think in nebulous terms is a great advantage. Even if a huge amount of information is presented to the human senses, the human mind can discard most of this information and focus only on the information that represents a relevant task. This ability of the human mind to deal only with the relevant information is related to its ability to process fuzzy information. By focusing only on relevant information to the task, the amount of information the brain has to deal with is reduced to a manageable level "(Zadeh, 1965).

The fuzzy system simulates a strategic/managerial choice on the variables of culture. It is noteworthy that a system gathers in its structure an intense analysis done by the researcher and collaborators. In this respect, the analysis takes into account the connection of variables of culture and the correspondence with its degree of force. In Figure 8 it can be seen that only the values and managerial human resource practices are not able to lead the existence of an organizational 
culture favorable to the management of the local culture.

The key factor of the analysis was to seek to identify the importance of values, organizational structure, and management of human resources practices in the management of the local culture process. The variables of each country demand for strategies that can lead to favorability management of local culture.

\section{Conclusion}

The integration of the study of culture can facilitate in the internationalization. Because of the links between organizations and local cultures, it is always necessary to measure the impact caused by a production plant. This is far beyond stakeholder analysis; it is necessary to unscramble the local culture and integrate it into human resources policies.

Culture is dynamic and interconnected with the organization. The management of culture, therefore, is not associated with the imposition of standard itineraries, but with the idea that there are variables that must be analyzed continuously. The organizational structure, human resources management practices, and values are elements that interact dynamically. The variables analyzed in the plant of Petrobras in Bolivia don't seem to be sufficient to consider the company has strong management of the local culture. Values, HR management practices and organizational structure shows that the company has management integrated into the culture, but it is subject to fluctuations of Bolivian political variables. Corporate values, though they seek for interfaces with the local culture, have not fully incorporated the country dynamics.

Negotiations with indigenous and peasant groups are constant, and the organizational structure, although they have favorable characteristics are still dependent on the state bureaucracy.

Bolivia attracts investors, but it is a country where the local culture with its multiple ethnicities requires being deciphered. Its political ideology demands the incorporation of strategies that inter-relate the risks involved.

The analysis of the local culture and interfaces with the organizational structure, values and management practices of human resources represent a complex action. The fuzzy theory presented a potential for checking a response.

Thus, this study model represents a preliminary analysis. The objective was to favor organizations so that they can verify their potential to manage the local culture. Modification actions can be simulated in human resource management practices, values, and structures. To optimize this study in future works, the idea is to test new qualitative variables integrated with fuzzy logic and increase the number of companies to be evaluated.

\section{Acknowledgments}

The São Paulo Research Foundation, FAPESP, Pró-Reitoria de Pesquisa (PROPe) São Paulo State University, Brazilian Petroleum Corporation (Petrobras).

\section{References}

Amendola, M., Castanho, M. J., Nääs, I. A., \& Souza, A. L. (2004). Análise matemática de condições de conforto térmico para avicultura usando a teoria dos conjuntos fuzzy. Biomatemática. Campinas, 14(1), 87-92.

Banco Central Do Brasil. BACEN. Capitais brasileiros no exterior. Estatísticas econômicas de capitais brasileiros no exterior (Brazilian capital abroad. Economic statistics of Brazilian capital abroad): 2001 a 2006; 2007 a 2011. 2013. Available at: http://www4.bcb.gov.br/rex/cbe/port/cbe.asp. Access in Feb. 2013.

Barros, L. C., \& Bassanezi, R. (2006). Tópicos de Lógica Fuzzy e Biomatemática (Topics of Fuzzy Logic and Biomathematics). Editora do IMECC-UNICAMP, 2006.

Baum, W. M. (2006). Compreender o behaviorismo: comportamento, cultura e evolução (Understanding behaviorism: Behavior, Culture and Evolution). Porto Alegre: Artmed, 2006.

Chávez, A. G. (2008). Inversiones brasileñas em Bolívia. Relatório final. Swiss Agency for Development and Cooperation e Fundação Centro de Estudos do Comércio Exterior. 2008.

Ciravegna, L., Lopez, L., \& Kundu, S. (2014). Country of origin and network effects on internationalization: a comparative study of SMEs from an emerging and developed economy. Journal of Business Research, 67, 916-923. https://doi.org/10.1016/j.jbusres.2013.07.011

Cohen, A., \& Fink, S. (2003). Comportamento organizacional (organizational behavior). São Paulo: Elsevier, 2003.

Cremasco, C. P., Gabriel Filho, L. R. A., \& Cataneo, A. (2010). Metodologia de determinação de funções de pertinência de controladores fuzzy para a avaliação energética de empresas de avicultura de postura (Methodology for determining membership functions of fuzzy controllers for the energy assessment of posture poultry enterprises.). Magazine: Energia na Agricultura, Botucatu, 25(1), 21-39. https://doi.org/10.17224/EnergAgric.2010v25n1p21-39 
Deadricka D. L., \& Stoneb, D. L. (2014). Human resource management: Past, present, and future. Human Resource Management Review, 24(3), 193-195. https://doi.org/10.1016/j.hrmr.2014.03.002

Deal, T. E., \& Kennedy, A. (2001). Corporate cultures, the rites, and rituals of corporate life. New York: Addison Wesley, 2001.

Dessler, G. (2011). Human Resource Management. Florida International University, 2011.

Fleury, A., Leme Fleury, M. A., \& Reis, G. G. (2010). El camino se hace al andar: la trayectoria de las multinacionales brasileñas. Universia Business Review, 25, 34-55.

Fleury, A., Leme Fleury, M. T., \& Borini, F. M. (2012). Is production the core competence for the internationalization of emerging country firms? International Journal of Production Economics, 140, 439-449. https://doi.org/10.1016/j.ijpe.2012.06.027

Fuller, R., Canós-Darós, L., \& Canós-Darós, M. J. (2012). Transparent fuzzy logic based methods for some human resources problems. Revista Electronica de Comunicaciones y Trabajos de ASEPUMA, 13, 27-41.

Gabriel Filho, L. R. A., Cremasco, C. P., Putti, F. F., \& Chacur, M. G. M. (2011). Application of fuzzy logic for the evaluation of livestock slaughtering. Agricultural Engineering, Jaboticabal, 31(4), 813-825. https://doi.org/10.1590/S0100-69162011000400019

Gabriel, F. L. R. A., Pigatto, G. A. S., \& Lourenzani, A. E. B. S. (2015) Fuzzy rule-based system for evaluation of uncertainty in cassava chain. Engenharia Agrícola, 35(2), 350-367.

Gaur, A. S., Kumar, V., \& Singh, D. (2014). Institutions, resources, and internationalization of emerging economy firms. Journal of World Business, 48, 12-20. https://doi.org/10.1016/j.jwb.2013.04.002

Hofstede, G. (2003). Culturas e organizações (Cultures and Organizations). Lisboa: Sílabo, 2003.

Ishii, K., \& Sugeno, M. (1985). A model of human evaluation process using fuzzy measure. Int Journal Man-Machine Studies, 22, 19-38. https://doi.org/10.1016/S0020-7373(85)80075-4

Keyton, J. (2005). Communication and organizational culture: a key to understanding work experiences. London: Sage, 2005.

Kira, M., \& Balkin, D. B. (2014). Interactions between work and identities: Thriving, withering, or redefining the self? Human Resource Management Review, 24(2), 131-143. https://doi.org/10.1016/j.hrmr.2013.10.001

Kosko, B. (1986). Fuzzy cognitive maps. Int. Journal Man-Machine Studies, 24, 65-75. https://doi.org/10.1016/S0020-7373(86)80040-2

Kotter, J. P., \& Heskett, J. L. (1994). Cultura de empresa (Company Culture): Rio de Janeiro: Jorge Zahar, 1994.

Kumar, V., Mudambi, R., \& Gray, S. (2013). Internationalization, innovation, and institutions: the 3I's underpinning the competitiveness of emerging market firms. Journal of International Management, 19, 203-206. https://doi.org/10.1016/j.intman.2013.03.005

Lu, J. (2011). Evaluation of Enterprise Human Resources Comprehensive Abilities Based on Managerial Psychology. Procedia Engineering, 16, 564-571. https://doi.org/10.1016/j.proeng.2011.08.1125

Martínez-Miranda, J., Alvarado, M., Aldea, A., \& Bañares-Alcántara, R. (2010). Modeling Human Behaviour at Work using Fuzzy Logic: The Challenge of Work Teams Configuration. In Proceedings of the World Congress on Engineering 2010.

Massad, E., Ortega, N. R. S., Barros, L. C., \& e STRUCHINER, C. J. (2008). Fuzzy Logic in Action: Applications in Epidemiology and Beyond. Studies in Fuzziness and Soft Computing. Springer, New York, 2008. https://doi.org/10.1007/978-3-540-69094-8

Mintzberg, H. et al. (2006). O processo da estratégia: conceitos, contextos e casos Selecionados (The strategy process: concepts, contexts and selected cases). Porto Alegre: Artmed, 2006.

Morgan, G. (2002). Imagens da organização (Images of the organization). São Paulo: Atlas, 2002.

Nancy, J., \& Adler, A. G. (2007). International dimensions of organizational behavior. Thomson Learning - Canada, 2007.

Pedrycz, W., \& Gomide, F. (1999). An introduction to fuzzy sets: Analysis and design. Massachusetts Institute of Technology. https://doi.org/10.7551/mitpress/3926.001.0001 
Peixoto, M. S. (2000). Sistemas dinâmicos e controladores fuzzy: um estudo da dispersão da morte súbita dos citros em São Paulo (Dynamical systems and fuzzy controllers: a study of the spread of citrus sudden death in São Paulo). Master's Dissertation, IMECC - UNICAMP, Campinas/SP.

Pereira, D. F., Bighi, C. A., Gabriel Filho, L. R. A., \& Gabriel, C. P. C. (2008). Sistema fuzzy para estimativa do bem-estar de matrizes pesadas (Fuzzy system to estimate the broiler breeder welfare). Engenharia Agrícola, Jaboticabal, 28(4), 624-633. https://doi.org/10.1590/S0100-69162008000400002

Petrobras. (2014). Available at: http://www.petrobras.com/es/quiene-somos/actividades. Access on: 18 Sep 2014.

Petrobras. (2015). Compromisso. Available at: http://www.petrobras.com/pt/paises/bolivia/compromisso/. Access on: 29 Jan 2015.

Putti, F. F., Gabriel Filho, L. R. A., Silva, A. O. da., Ludwig, R., \& Gabriel, C. P. C. (2014). Fuzzy logic to evaluate vitality of catasetum fimbiratum species (Orchidacea). Irriga, Botucatu, 19(3), 405-413. https://doi.org/10.15809/irriga.2014v19n3p405

Putti, F. F., Gabriel, F. L. R. A., Cremasco, C. P., Bonini, N. A., Bonini, C. S. B., \& Reis A. R (2017). A Fuzzy mathematical model to estimate the effects of global warming on the vitality of Laelia purpurata orchids. Mathematical Biosciences, 288, 124-129. https://doi.org/10.1016/j.mbs.2017.03.005

Ribacionka, F. (1999). Sistemas computacionais baseados em lógica fuzzy (Computer systems based on fuzzy logic). Master's Dissertation, Universidade Mackenzie, São Paulo, SP.

Rivero, W. P. (2012). Pueblos indígenas de Bolivia. Retrieved April 17, 2020, from http://www.amazonia.bo/wen.php/

Rudy, L. J. (2014). Defining the organizational structure of your business. Diponível em: http://business.tutsplus.com/articles/defining-the-organizational-structure-of-your-business--cms-20338. Access on 17 Nov. 2014.

Ruegenberg, R. D. A. (2013). El sector hidrocarburos. Unidad de análisis de políticas sociales y económicas. Documentos periódicos. Diagnósticos Sectoriales. 2009. Available at: http://www.udape.gob.bo/index.php?option=com_wrapper\&view=wrapper\&Itemid=80. Access on Feb. 2013.

Sahlins, M. D. (2003). Cultura e razão prática (Culture and Practical reason). Rio de Janeiro: Jorge Zahar, 2003.

Schein, E. (1986). Psicologia organizacional (Organizational psychology). Rio de Janeiro: Prentice-Hall, 1986.

Shaw, I. S., \& Simões, M. G. (2011). Controle e Modelagem Fuzzy (Fuzzy Control and Modeling). Editora Edgard Blucher Ltda, 2011, 2nd Edition.

Spector, P. E. (2012). Psicologia nas Organizações (Psychology in Organizations). São Paulo, Ed. Saraiva, 2012.

Suárez, R. V. (2009). La nacionalización de los hidrocarburos bolivianos en la presidência de Evo Morales Ayma. Revista de Estudos Latinoamericanos. Centro de Investigaciones sobre America Latina Y el Caribe. México, 49, 2009.

Swigger, K., Alpaslan, F., Brazile, R., \& Monticino, M. (2004). Effects of culture on computer-supported international collaborations. Int. Journal Human-Computer Studies, 60, 365-380. https://doi.org/10.1016/j.ijhcs.2003.10.006

Zadeh, L. A. (1965). Fuzzy sets. Information and Control, Berkeley, 8(1), 338-365, 1965. https://doi.org/10.1016/S0019-9958(65)90241-X

Zemková, B., \& Talašová, J. (2011). Fuzzy Sets in HR Management. Acta Polytechnica Hungarica, 8(3), 113-124.

\section{Copyrights}

Copyright for this article is retained by the author(s), with first publication rights granted to the journal.

This is an open-access article distributed under the terms and conditions of the Creative Commons Attribution license which permits unrestricted use, distribution, and reproduction in any medium, provided the original work is properly cited. 